\title{
Condition of mineralized tooth tissue in a population of 15-year-old adolescents living in a region of Ukraine with slightly exceeded fluorine concentration in the water
}

\author{
Teresa Bachanek ${ }^{1, A} \oplus$, Barbara Hendzel ${ }^{1, A-F} \oplus$, Ewa Wolańska ${ }^{1, A-F} \oplus$, Dariusz Samborski ${ }^{1, A-F} \oplus$, \\ Zbigniew Jarosz ${ }^{2, B, D \oplus}$, Karolina Maria Pitura ${ }^{2, A-F} \oplus$, Katarzyna Dzida ${ }^{2, C}{ }^{\infty}$, Mariusz Podymniak ${ }^{2, C} \oplus$, \\ Barbara Tymczyna-Borowicz ${ }^{1, D \oplus}$, Agata Niewczas ${ }^{1, B \oplus}{ }^{\oplus}$, Volodymyr Shybinskyy, ${ }^{3, B} \oplus$, \\ Andryi Zimenkovsky ${ }^{3, A}$. \\ ${ }^{1}$ Department of Conservative Dentistry and Endodontics, Medical University, Lublin, Poland \\ 2 Department of Cultivation and Fertilization of Horticultural Plants, University of Life Sciences, Lublin, Poland \\ ${ }^{3}$ Danylo Halytsky National Medical University, Lviv, Ukraine \\ A - Research concept and design, B - Collection and/or assembly of data, C - Data analysis and interpretation, \\ $D$ - Writing the article, E-Critical revision of the article, F - Final approval of article
}

Bachanek T, Hendzel B, Wolańska E, Samborski D, Jarosz Z, Pitura KM, Dzida K, Podymniak M, Tymczyna-Borowicz B, Niewczas A, Shybinskyy V, Zimenkovsky A. Condition of mineralized tooth tissue in a population of 15-year-old adolescents living in a region of Ukraine with slightly exceeded fluorine concentration in the water. Ann Agric Environ Med. 2019; 26(4): 623-629. doi: 10.26444/aaem/110013

\section{Abstract}

Introduction. Fluorine is a common element in nature; however, the difference between a beneficial dose and a toxic dose for the organisms is small. The main source of fluoride for humans is water in addition to food.

Objective. The aim of this study was to estimate the degree of severity of pathological changes, namely, caries or fluorosis, in the mineralized tooth tissue of 15 -year-old adolescents with respect to their hygienic and nutritional habits, and the content of fluorine in drinking water, soil and plant products.

Materials and method. 100 adolescents aged 15 from schools in Sosniłka, L'viv region, were examined. The condition of mineralized tooth tissue was evaluated by the caries severity, expressed by the mean number D3MFT, caries frequency and value of the SIC index. Fluorine in plant material and soil were determined according to the PN-G-04543:1982 standard, and water according to the PN-EN ISO 10304 - 1: 2009+ AC: 2012 standard.

Results. Severity of caries disease expressed by the D3MFT number in the examined group of 15-year-olds was 3.39; in the group of girls -3.08 , and in the group of boys -3.76 . In the examined group, the average number of teeth with fluorosis was 7.59. Value of the SIC index among the examined population of students ( $n-31)$ was 6.26: 5.89 ( $n-18$ ) for girls and 7.31 ( $n-13$ ) for boys. Fluorine concentration in the water was $0.78-1.25(\mathrm{mg} \cdot \mathrm{dm}-3)$. In the soil, it also did not vary across the sampled areas and amounted, on average, to $176 \mathrm{mg} \cdot \mathrm{dm}-3$. The biggest fluorine content noted in the dry mass of beetroots was 3.50 (mg F. kg), and the lowest - 3.34 (mg F. kg).

Conclusions. Close to optimal fluorine content lowers caries severity and frequency of fluorosis. Optimal fluorine content in drinking water and food does not require additional diet supplementation

\section{Key words}

tooth tissue, fluorine, chemical composition of water

\section{INTRODUCTION}

Dental fluorosis is a pathological condition developing during the period of amelogenesis and resulting from the exceeded exposure of teeth tissue to fluorine compounds, i.e. when the total (above optimal) dose of fluorine is present during the critical period for permanent teeth (perinatal to 7 years of age). Clinical image of the enamel changes depends on the severity of the disease. Enamel can be opaque, rough or dull. Single strands may merge in opalescent spots, chalkwhite or brown concavities. There may also be a total lack of enamel which leads to a change in the crown of the tooth [1]. The severity of fluorosis depends on the concentration

Address for correspondence: Karolina Maria Pitura, Department of Cultivation and Fertilization of Horticultural Plants, Poland

E-mail: karolina.pitura@up.lublin.pl

Received: 23.01.2019; accepted: 12.06.2019; first published: 11.07.2019 of fluorine compounds in the drinking water, groceries and tooth-paste, exposure time and individual predispositions $[2,3,4]$. According to Skorkowska-Zieleniewska et al. [5], fluorine accessibility from water is $60 \%$ and from food $35 \%$. Fluorosis mostly affects the permanent teeth: premolars, second molars, upper incisors and fangs, where the mineralization period occurs later in life [6], most probably due to the greater accessibility of fluorine compounds to older children. As a result of ongoing industrialisation, hence, polluting the environment with fluorine compounds, the WHO recommends that optimal dose of fluorine in drinking water as $0.5-1$ ppm [7].

Fluorine pollution affects all elements of the ecosystem. Fluorine compounds in the soil are found mainly in the humus layer and the fluorine content depends on organic substances and the bedrock [8]. Since water, soil and atmosphere are the main sources of fluorine for plants, its content in the 
above-mentioned environments indirectly influences its accessibility for humans [9]. Plants uptake fluorine through diffusionn and the cell wall constitutes the main barrier to its accumulation [10]. Excessive concentration of this element in plants changes enzymes activity, adversely affects the process of photosynthesis, inhibits growth and increases biomass [11].

\section{OBJECTIVE}

The aim of this study was to estimate the degree of severity of pathological changes, namely, caries or fluorosis, in the mineralized tooth tissue of 15-year-old adolescents with respect to their hygienic and nutritional habits, the content of fluorine in drinking water, soil and plant products.

\section{MATERIALS AND METHOD}

A group of 15-year-old adolescents (index age group approved by the WHO) attending schools in Sosnilka, Lviv region of Ukraine, was clinically tested. In total, there were 100 participants of both genders. The tests were conducted in standardized conditions with disposable dental kits, and attention paid to sterility and non-invasiveness for the patients. All examinations were carried out in dental surgeries, secured and prepared by the testing team with disposable materials. The tests were performed in the light of a lamp for dental use, a mirror and a WHO probe. Data were collected in anonymous and coded case report files. Clinical evaluation of the patients' oral health was carried out in compliance with WHO guidelines and suggested criteria (Oral Health Surveys: Basic Method, $5^{\text {th }}$ Edition, 2013). All the doctors conducting the tests had received training connected with the calibration process, from which a mean standard error was estimated. Cohen's kappa compatibility factor of the test results was 0.97 . The results were verified by secondary random sampling of $10 \%$ of patients. The condition of mineralized tooth tissue was evaluated by the caries severity, expressed by the mean number D3MFT, caries frequency and value of the SIC index.

Evaluation of the condition of mineralized tooth tissue in view of fluorosis was performed in compliance with the WHO guidelines and Dean's criteria [12]:

Do - correct dentition /enamel surface is smooth and shiny of creamy-white colour.

D1 - questionable fluorosis / enamel surface with clearly marked deviations from correct transparency (a few white spots).

D2 -very mild fluorosis / small, whitish, opaque, irregular patches on less than $1 / 4$ of the tooth surface.

D3 - mild fluorosis / white opaqueness of the enamel is more widespread, but does not exceed $50 \%$ of the tooth enamel.

D4 - moderate fluorosis / enamel surface is considerably damaged with frequent brown stains.

D5 - severe fluorosis / the whole surface is damaged; hypoplasia is so extensive that tooth shape can be altered; either small or extensive pitting or brown discolorations; tooth often corroded.

Socio-medical tests constituted the second part of the research. Questions, adjusted to the age of the patients were included in the questionnaires, coded with the same numbers as the patients case report files. The questions concerned nutritional and hygienic habits and included the following parameters: frequency of fresh fruit and vegetable consumption, frequency of teeth brushing, use of fluoride toothpaste. The obtained results were statistically analyzed. Values for measurable parameters were presented as values of average, median, minimum and maximum values, lower and upper quartile and standard deviation, and for the immeasurable ones, as multiplicity and percentage.

Test $\mathrm{Chi}^{2}$ was used for quality features to detect the dependence between analysed variables, whereas the MannWhitney $U$ test was used in order to examine differences between two groups. Level of significance of $p<0.05$ indicated statistically significant differences or dependencies. The database and statistical studies were performed on Statistica 9.1 software (StatSoft, Poland).

Plant material, water and soil were sampled from the area of Sosnilka village, and randomly divided into three parts. Three farms were chosen from each part for analysis of vegetables (beetroot), water and soil. Fluorine content in the sampled material was determined. Plant material and soil were determined according to the PN-G-04543:1982 standard, and water according to PN-EN ISO $10304-1$ : 2009+ AC: 2012 standard by the ion chromatography method (IC).

\section{RESULTS}

Because 10 questionnaires were inadequately completed, only 90 of the 10015 -year-old participants, indigenous inhabitants of Sosnilka, were qualified for test analysis. Among the middle and high school students, $54.44 \%$ (n-49) were girls and $45.56 \%$ (n-41) boys.

Caries frequency was estimated at $86.67 \%$ and was lower in the group of girls (81.63\%) than in the group of boys $(92.68 \%)$

Severity of caries disease expressed by the D3MFT number in the examined group of 15-year-olds was 3.39; in the group of girls -3.08 , and in the group of boys -3.76 . In the examined group, the mean value of D3T was $2.44 ; 2.39$ for girls and 2.51 for boys. Mean value of the MT number was 0.035 and pertained to boys only. Mean value of number the FT was higher for boys (1.17) and lower for girls (0.69). The differences were not statistically significant. Table 1 presents mean values of the D3MFT number and its components $\mathrm{D}_{3} \mathrm{~T}$, MT, MF in the group of 15-year-olds.

Table 2 presents mean values of number D3MFT and its components for patients diagnosed with fluorosis and for patients without fluorosis. Mean value of D3MFT in the group with fluorosis -2.59 and in the group of people without fluorosis -3.73 . The differences were not statistically significant. Statistically significant differences were observed only for the FT component -0.48 and 1.10 , respectively $(\mathrm{p}=0.020)$.

Table 3 shows the statistically significant correlation between the number of teeth with fluorosis and the D3T value ( $p=0.015)$; FT ( $p=0.047)$; D3MFT $(p<0,001)$; namely, more teeth with fluorosis corresponded with lower values of D3T, FT, D3MFT (negative correlation).

No statistically significant correlation between the MT value and the number of teeth with fluorosis $(\mathrm{p}=0.614)$ was noted. 
Table 1. Mean values of D3MFT and its components in the examined group of 15-year-old adolescents with respect to gender

\begin{tabular}{|c|c|c|c|c|c|c|c|c|c|}
\hline Specification & Gender & $\mathrm{M}$ & Me & Min. & Max. & Q1 & Q3 & SD & Difference at $p$ level \\
\hline \multirow{3}{*}{ D3T } & Female & 2.39 & 2 & 0 & 11 & 0 & 3 & 2.46 & \multirow{2}{*}{$\begin{array}{l}Z=0.124 \\
p=0.901\end{array}$} \\
\hline & Male & 2.51 & 2 & 0 & 10 & 0 & 4 & 2.82 & \\
\hline & Total & 2.44 & 2 & 0 & 11 & 0 & 3 & 2.62 & - \\
\hline \multirow[b]{2}{*}{ MT } & Female & 0.00 & 0 & 0 & 0 & 0 & 0 & 0.00 & \multirow{2}{*}{$\begin{array}{l}Z=-2.539 \\
p=0.124\end{array}$} \\
\hline & Male & 0.07 & 0 & 0 & 2 & 0 & 0 & 0.35 & \\
\hline \multirow{3}{*}{ FT } & Female & 0.69 & 0 & 0 & 4 & 0 & 1 & 1.02 & \multirow{2}{*}{$\begin{array}{l}Z=-1.395 \\
p=0.163\end{array}$} \\
\hline & Male & 1.17 & 1 & 0 & 8 & 0 & 2 & 1.67 & \\
\hline & Total & 0.91 & 0 & 0 & 8 & 0 & 1 & 1.37 & - \\
\hline \multirow[b]{2}{*}{ D3MFT } & Female & 3.08 & 3 & 0 & 11 & 1 & 4 & 2.64 & \multirow{2}{*}{$\begin{array}{l}Z=-1.051 \\
p=0.293\end{array}$} \\
\hline & Male & 3.76 & 3 & 0 & 12 & 2 & 5 & 3.00 & \\
\hline
\end{tabular}

M - mean; Me - median; Min. - minimum value; Max. - maximum value; Q1 - bottom quartile; Q3 - upper quartile; SD - standard deviation; p - statistical significance.

Table 2. Mean values of D3MFT and its components in the examined group of 15-year-old adolescents affected and unaffected by dental fluorosis

\begin{tabular}{|c|c|c|c|c|c|c|c|c|c|}
\hline Specification & Dental fluorosis & M & $\mathrm{Me}$ & Min. & Max. & Q1 & Q3 & SD & Difference at $p$ level \\
\hline \multirow{2}{*}{ D3T } & No $(\mathrm{N}=63)$ & 2.60 & 2.0 & 0.00 & 11.00 & 0.00 & 4.00 & 2.78 & \multirow{2}{*}{$\begin{array}{l}Z=0.566 \\
p=0.571\end{array}$} \\
\hline & Yes $(\mathrm{N}=27)$ & 2.07 & 2.0 & 0.00 & 9.00 & 0.00 & 3.00 & 2.20 & \\
\hline MT & Yes $(\mathrm{N}=27)$ & 0.04 & 0.0 & 0.00 & 1.00 & 0.00 & 0.00 & 0.19 & $\begin{array}{l}Z=-0.586 \\
p=0.557\end{array}$ \\
\hline FT & No $(\mathrm{N}=63)$ & 1.10 & 1.0 & 0.00 & 8.00 & 0.00 & 2.00 & 1.48 & $\begin{array}{l}Z=2.324 \\
p=0.020\end{array}$ \\
\hline \multirow{2}{*}{ D3MFT } & No $(\mathrm{N}=63)$ & 3.73 & 3.0 & 0.00 & 12.00 & 2.00 & 5.00 & 2.99 & \multirow{2}{*}{$\begin{array}{l}Z=1.742 \\
p=0.081\end{array}$} \\
\hline & Yes $(\mathrm{N}=27)$ & 2.59 & 2.0 & 0.00 & 9.00 & 1.00 & 4.00 & 2.19 & \\
\hline
\end{tabular}

M - mean; Me - median; Min. - minimum value; Max. - maximum value; Q1 - bottom quartile; Q3 - upper quartile; SD - standard deviation; $\mathrm{p}$ - statistical significance.

Table 3. Mean values of D3MFT and its components in the examined group of 15-year-old adolescents with regard to the number of teeth with dental fluorosis

\begin{tabular}{lcc}
\hline Specification & $R$ & $p$ \\
\hline D3T & -0.465 & $=0.015$ \\
\hline MT & 0.102 & $=0.614$ \\
\hline FT & -0.386 & $=0.047$ \\
\hline D3MFT & -0.645 & $<0.001$ \\
\hline
\end{tabular}

$\mathrm{R}$ - correlation coefficient; $\mathrm{p}$ - statistical significance

The value of SIC index among the examined population of students (n-31) was 6.26, with 5.89 (n-18) for girls and 7.31 (n-13) for boys (Tab. 4).

Table 5 covers the number of people diagnosed with fluorosis. In the tested group it was present in $30 \%$ of patients $(n=27)$; in $28.57 \%$ of girls $(n=14)$ and in $31.71 \%$ of boys $(n=13)$. No statistically significant difference in correlation with gender and fluorosis incidence was noted $(\mathrm{p}=0.746)$.

Table 4. Mean values of SIC index in the examined group of 15-year-old adolescents with respect to gender

\begin{tabular}{lcccccccc}
\hline Specification & M & Me & Min. & Max. & Q1 & Q3 & SD & $\begin{array}{c}\text { Difference at } \\
\text { plevel }\end{array}$ \\
\hline Total $(\mathrm{N}=34)$ & 626 & 5 & 4 & 12 & 4 & 7 & 2.37 & - \\
\hline Female $(\mathrm{N}=18)$ & 5.89 & 5 & 4 & 11 & 4 & 7 & 2.03 & $\mathrm{U}=245.5$ \\
\cline { 1 - 3 }$(\mathrm{N}=13)$ & 7.31 & 6 & 5 & 12 & 5 & 9 & 2.63 & $\mathrm{p}=0.089$ \\
\hline
\end{tabular}

M - mean; Me - median; Min. - minimum value; Max. - maximum value; Q1 - bottom quartile; Q3 - upper quartile; SD - standard deviation; $\mathrm{p}$ - statistical significance.
Table 5. Number of examined group of 15 -year-old adolescents with dental flurosis regarding gender

\begin{tabular}{|c|c|c|c|}
\hline \multirow[b]{2}{*}{ Specification } & \multicolumn{2}{|c|}{ Dental fluorosis } & \multirow{2}{*}{$\begin{array}{c}\text { Difference a } \\
\quad \text { p level }\end{array}$} \\
\hline & $\begin{array}{l}\text { Unaffected } \\
\text { adolescents }\end{array}$ & $\begin{array}{c}\text { Affected } \\
\text { adolescents }\end{array}$ & \\
\hline \multirow{2}{*}{ Female } & 35 & 14 & \multirow{4}{*}{$\begin{array}{c}\mathrm{Chi}^{2}=0.105 \\
\mathrm{df}=1 \\
\mathrm{p}=0.746\end{array}$} \\
\hline & $71.43 \%$ & $28.57 \%$ & \\
\hline \multirow{2}{*}{ Male } & 28 & 13 & \\
\hline & $68.29 \%$ & $31.71 \%$ & \\
\hline Total & $\begin{array}{c}63 \\
70.00 \%\end{array}$ & $\begin{array}{c}27 \\
30.00 \%\end{array}$ & - \\
\hline
\end{tabular}

In the examined group, the average number of teeth with fluorosis was 7.59; 9.93 for girls and 5.08 for boys. Comparing the tests results, it was concluded that there were more teeth with fluorosis in the population of girls (median: 7; interquartile range: $4-16)$ than in the population of boys (median: 4; interquartile range: $2-6$ ), which was statistically significant $(\mathrm{p}=0.038)$ (Tab. 6).

Table 6. Number of teeth with dental fluorosis in examined group of 15-year-old adolescents with respect to gender

\begin{tabular}{|c|c|c|c|c|c|c|c|c|c|}
\hline Specification & $\mathrm{N}$ & M & Me & Min. & Max. & Q1 & Q3 & SD & $\begin{array}{c}\text { Difference at } \\
\text { p level }\end{array}$ \\
\hline Total & 27 & 7.59 & 4 & 1 & 28 & 3 & 9 & 6.99 & - \\
\hline Female & 14 & 9.93 & 7 & 2 & 28 & 4 & 16 & 8.04 & \multirow{2}{*}{$\begin{array}{c}U=48.0 \\
p=0.038\end{array}$} \\
\hline Male & 13 & 5.08 & 4 & 1 & 19 & 2 & 6 & 4.75 & \\
\hline
\end{tabular}

$\mathrm{N}$ - number; $\mathrm{M}$ - mean; Me - median; Min. - minimum value; Max. - maximum value; $\mathrm{Q} 1$ - bottom quartile; Q3 - upper quartile, SD - standard deviation; $p$ - statistical significance. 
In the examined group, there were 27 cases (6.67\%), (n-6) of questionable fluorosis (D1), and 21 cases (23.33\%) of very mild to severe fluorosis (D2-D5). In order to determine which teeth were most frequently affected by fluorosis, the dentition was divided into 6 sextants: sextant I: average number of teeth affected by fluorosis -0.67 , sextant II: 3.52 , sextant III: 0.96 , sextant IV: 0.48 , sextant V: 1.30 and in sextant VI: 0.67 . The majority of teeth affected by fluorosis was observed in sextant II (Q1-Q3: 1-6) (Tab. 7).

Table 7. Number of teeth with dental fluorosis in examined group of 15 -year-old adolescents regarding teeth sextants

\begin{tabular}{lcccccccc}
\hline Sextants & N & M & Me & Min. & Max. & Q1 & Q3 & SD \\
\hline Sextant I (18-14) & 27 & 0.67 & 0 & 0 & 4 & 0 & 1 & 1.18 \\
\hline Sextant II(13-23) & 27 & 3.52 & 4 & 0 & 6 & 1 & 6 & 2.52 \\
\hline Sextant III(24-28) & 27 & 0.96 & 1 & 0 & 4 & 0 & 2 & 1.22 \\
\hline Sextant IV (38-34) & 27 & 0.48 & 0 & 0 & 4 & 0 & 1 & 0.98 \\
\hline Sextant V (33-43) & 27 & 1.30 & 0 & 0 & 6 & 0 & 2 & 2.30 \\
\hline Sextant VI (44-48) & 27 & 0.67 & 0 & 0 & 4 & 0 & 1 & 1.24 \\
\hline
\end{tabular}

M - mean; Me - median; Min. - minimum value; Max. - maximum value; Q1 - bottom quartile; Q3 - upper quartile; SD - standard deviation.

Socio-medical analysis shows that all examined patients brushed their teeth with fluoride toothpaste and water. In the group of people with diagnosed fluorosis, $34.38 \%(n=11)$ brushed their teeth once a day, $29.02 \%(n=16)$ at least twice a day. Three patients who brushed their teeth less than once a day were not included in the analysis. The number of daily hygienic treatments did not affect the incidence of fluorosis $(\mathrm{p}=0.607)$ (Tab. 8). Table 9 presents the correlation between incidence of fluorosis and the use of fluoride toothpaste. Questionnaire responses show that 61 participants (67.77\%) brushed their teeth with fluoride toothpast; among them, $31.15 \%(n=19)$ were diagnosed with fluorosis. $28.57 \%(n=8)$ of the participants who did not use fluoride toothpaste were

Table 8. Prevalence of dental fluorosis and frequency of teeth brushing in examined group of 15-year-old adolescents

\begin{tabular}{|c|c|c|c|}
\hline \multirow[b]{2}{*}{ Frequency of teeth brushing } & \multicolumn{2}{|c|}{ Dental fluorosis } & \multirow{2}{*}{$\begin{array}{c}\text { Difference at } \\
\text { p level }\end{array}$} \\
\hline & $\begin{array}{l}\text { Unaffected } \\
\text { adolescents }\end{array}$ & $\begin{array}{c}\text { Affected } \\
\text { adolescents }\end{array}$ & \\
\hline \multirow{2}{*}{ Once a day } & 21 & 11 & \multirow{4}{*}{$\begin{array}{c}\mathrm{Chi}^{2}=0.264 \\
\mathrm{df}=1 \\
\mathrm{p}=0.607\end{array}$} \\
\hline & $65.63 \%$ & $34.38 \%$ & \\
\hline \multirow{2}{*}{ Twice or more times a day } & 39 & 16 & \\
\hline & $70.91 \%$ & $29.09 \%$ & \\
\hline \multirow{2}{*}{ Total * } & 60 & 27 & \multirow{2}{*}{-} \\
\hline & $70.00 \%$ & $30.00 \%$ & \\
\hline
\end{tabular}

The analysis does not include three people who brushed their teeth less than once a day.

Table 9. Use of fluoride toothpaste and prevalence of dental fluorosis in examined group of 15-year-old adolescents

\begin{tabular}{|c|c|c|c|}
\hline \multirow[b]{2}{*}{ Use of fluoride toothpaste } & \multicolumn{2}{|c|}{ Dental fluorosis } & \multirow{2}{*}{$\begin{array}{c}\text { Difference AT } \\
\text { p level }\end{array}$} \\
\hline & $\begin{array}{l}\text { Unaffected } \\
\text { adolescents }\end{array}$ & $\begin{array}{c}\text { Affected } \\
\text { adolescents }\end{array}$ & \\
\hline \multirow{2}{*}{ Yes } & 42 & 19 & \multirow{4}{*}{$\begin{array}{c}\mathrm{Chi}^{2}{ }_{\text {Yatesa }}<0.001 \\
\mathrm{df}=1 \\
\mathrm{p}=0.998\end{array}$} \\
\hline & $68.85 \%$ & $31.15 \%$ & \\
\hline \multirow{2}{*}{ No } & 20 & 8 & \\
\hline & $71.43 \%$ & $28.57 \%$ & \\
\hline \multirow{2}{*}{ Total } & 62 & 27 & \multirow{2}{*}{-} \\
\hline & $69.66 \%$ & $30.34 \%$ & \\
\hline
\end{tabular}

Table 10. Frequency of fresh vegetables and fruits consumption and prevalence of dental fluorosis in examined group of 15-year-old adolescents

\begin{tabular}{|c|c|c|c|}
\hline \multirow[b]{2}{*}{ Specification } & \multicolumn{2}{|c|}{ Dental fluorosis } & \multirow{2}{*}{$\begin{array}{c}\text { Difference at } \\
\text { p level }\end{array}$} \\
\hline & $\begin{array}{l}\text { Unaffected } \\
\text { adolescents }\end{array}$ & $\begin{array}{c}\text { Affected } \\
\text { adolescents }\end{array}$ & \\
\hline \multirow{2}{*}{ Every day } & 45 & 21 & \multirow{4}{*}{$\begin{array}{c}\mathrm{Chi}^{2}{ }_{\text {Yatesa }}=0.133 \\
\mathrm{df}=1 \\
p=0.716\end{array}$} \\
\hline & $68.18 \%$ & $31.82 \%$ & \\
\hline \multirow{2}{*}{ Every 2-3 days or once a week } & 18 & 6 & \\
\hline & $75.00 \%$ & $25.00 \%$ & \\
\hline \multirow{2}{*}{ Total } & 63 & 27 & \\
\hline & $70.00 \%$ & $30.00 \%$ & \\
\hline
\end{tabular}

also affected by fluorosis. However, the differences were not statistically significant $(\mathrm{p}=0.998)$.

Table 10 shows the relation between prevalence of fluorosis and consumption of fresh fruit and vegetables. Fluorosis was diagnosed in $31.82 \%(n=21)$ of patients eating fresh fruit and vegetables every day, and in $25.00 \%(n=6)$ of those eating vegetables every 2-3 days or once a week. There was no statistically significant correlation between the frequency of eating fresh fruit and vegetables and prevalence of fluorosis $(\mathrm{p}=0.716)$.

The data concerning frequency of fresh vegetables and fruit consumption by the patients diagnosed with fluorosis is presented in Table 11. Taking into consideration only the patients with fluorosis, a statistically significant difference was observed in the number of teeth with fluorosis between those who ate fruit and vegetables every day and more often $(\mathrm{U}=27.0, \mathrm{p}=0.036)$, and those who ate them every $2-3$ days or only once a week.

Table 11. Mean number of teeth with dental fluorosis and frequency of fresh vegetables and fruits consumption in examined group of 15-yearold adolescents

\begin{tabular}{|c|c|c|c|c|c|c|c|c|}
\hline Specification & M & $\mathrm{Me}$ & Min. & Max. & Q1 & Q3 & SD & $\begin{array}{l}\text { Difference } \\
\text { at p level }\end{array}$ \\
\hline Every day & 8.76 & 6.0 & 2.00 & 28.00 & 4.00 & 9.00 & 7.42 & \multirow{2}{*}{$\begin{array}{c}U=27.0 \\
p=0.036\end{array}$} \\
\hline $\begin{array}{l}\text { Every } 2-3 \text { days or } \\
\text { once a week }\end{array}$ & 3.50 & 2.5 & 1.00 & 9.00 & 2.00 & 4.00 & 2,88 & \\
\hline
\end{tabular}

Table 12 presents the results of chemical analysis of fluoride content in water, soil, and plant material. The analysis concludes that fluorine concentration levels were not significantly different between the three studied materials in the sampling area. Fluorine concentration in the water was $0.78-1.25\left(\mathrm{mg} \mathrm{dm}^{-3}\right)$. In the soil, it also did not vary across the sampled areas and amounted, on average, to $176 \mathrm{mg} \cdot \mathrm{dm}^{-3}$. The biggest fluorine content noted in the dry mass of beetroots was 3.50 (mg F. kg), and the lowest - 3.34 (mg F. kg).

Table 12. Fluorine content in soil, water and vegetables in Sosnilka

\begin{tabular}{lccc}
\hline Research area & Water $\left(\mathrm{mg} \cdot \mathrm{dm}^{-3}\right)$ & Soil $\left(\mathrm{mg} \cdot \mathrm{dm}^{-3}\right)$ & Plant material $(\mathrm{mg} \cdot \mathrm{kg})$ \\
\hline I & 0,78 & 174 & 3,40 \\
\hline II & 1,25 & 177 & 3,50 \\
\hline III & 1,08 & 177 & 3,34 \\
\hline Me & 1,10 & 177 & 3,40 \\
\hline Mean & 1,04 & 176 & 3,41
\end{tabular}




\section{DISCUSSION}

The research revealed that caries frequency in the group of 15-year-old adolescents living in the area of Sosnilka was high - 86.67\%. Studies conducted in Malawi by Msyamboz et al. [13] showed that caries frequency was $21.9 \%$, evidently much lower. Similarly, Chinese and Mexican authors observed a considerably lower caries frequency - $24.4 \%$ [14] and $48.6 \%$ [15], respectively. Higher values of caries frequency were noted in United Arab Emirates - 65\% [16] and Iran - 75.5\% [17]. However, the highest caries frequency was recorded in youths from cities in north-west Russia - 91.8\% [18] and in Lithuania - 92.9\% [19].

Caries severity was estimated with the value of mean D3MFT number. In the available literature, published values of mean D3MFT number varied and fluctuated from 0.45 in China [14] and 5.44 in Lebanon [20] to 5.6 in Lithuania [19]. Own data is lower than the results obtained from examining 15-year-old youths in L'viv, Ukraine, in 2012 - 5.18 [21] and 2015 - 5.58 [22]. Values of the D3MFT number similar to those obtained in Sosnilka - 3.39, were also recorded in Greece - 3.19 [23], Georgia - 3.51 [24], and India - 3.82 [25].

The results of epidemiological data of mineralized tooth tissue, based on analysis of the D3MFT number, should be considered in correlation with the values of its particular components - D3T, MT and FT.

Studies conducted in L'viv in 2012 revealed the following values of particular components of D3MFT: D3T - 2.52, MT -0.05 , FT - 2.61 [21], and in 2015: D3T - 3.35, MT - 0.06, FT -2.86 [22]. The studies by Smolar showed that the D3MFT number in Sosnilka was 2.00 [21]. D3T values obtained in different countries varied considerably. The D3T value in a group of 15-year-old adolescents from Russia was 2.61 [18], while in Macedonia it was only 0.56 [26]. The ratio of D3T to MT and FT may indirectly expose the quality of dental care and pro-health habits of the population.

In own research, in order to identify patients with a high severity of caries, the SIC index (Significant Caries Index) was applied. Statistical analysis showed that the index value was 6.26. Considerably higher values (10.8) were recorded in 2011 for a population of Polish children [27]. Research conducted in 2015 L'viv, Ukraine, concluded that the SIC value for 15-year-old adolescents was 10.13, and for peer adolescents from Lublin, eastern Poland - 7.3 [22]. Hilt recorded SIC value of 8.20 [28], while for 15-year-old youths from Macedonia - 8.93 [26], and for Greek youths - 7.07 [23]. A much lower SIC value of 3.46 was obtained from studies by Pontiago-Loyola et al. [15].

Dentists working in Sosnilka area in 1994 and 2012 reported a fluorine level in drinking water of $4.00 \mathrm{ppm}$ and 1.64 ppm, respectively (Fig. 1-5). After changes in water supply and modernisation of the water supply network, in 2016 the fluorine level was estimated at $1.01 \mathrm{ppm}$, on average, although in some research areas it was $1.25 \mathrm{ppm}$. The examined group of 15-year-old adolescents was exposed to high fluoride levels through odontogenesis. Fluorine concentration over $1 \mathrm{ppm}$ in drinking water increases aluminum adsorption, causing degenerative changes and collagen breakdown [30].A fluorine content over $1.5 \mathrm{ppm}$ causes mottling of teeth, while its concentration above 3.0 ppm leads to skeletal fluorosis [10]. In studies conducted in Poland by Jędra et al. [31], the fluorine content in drinking water was estimated as low: $0.09 \mathrm{mg} \cdot \mathrm{dm}^{3}$ in (Sosnowiec) -
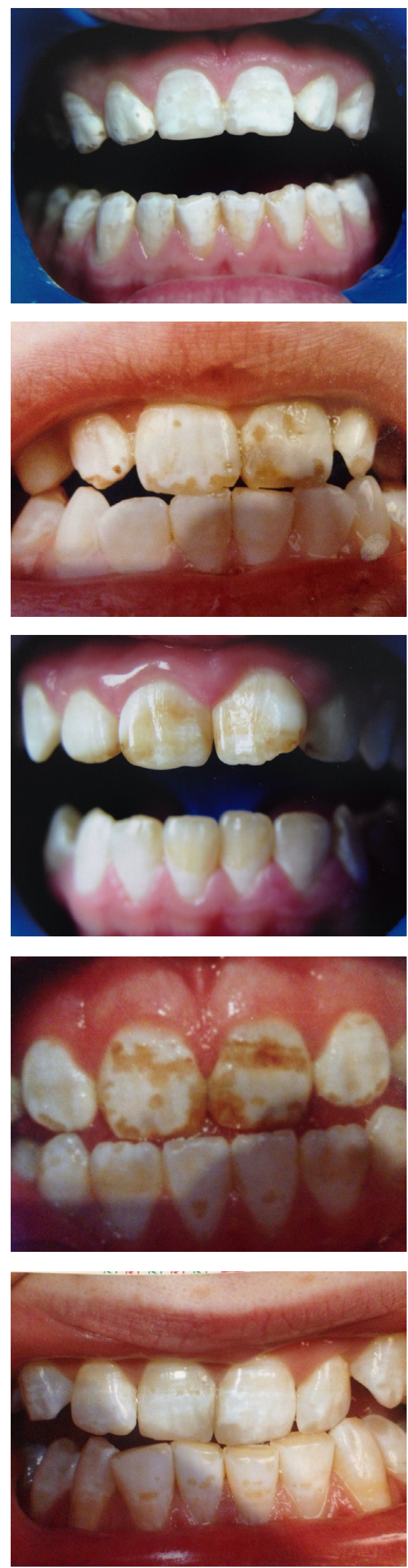

Figure 1-5. Clinical cases of fluorosis according to Dean Classification (D3-D5) in examined group 
$0.32 \mathrm{mg} \cdot \mathrm{dm}^{3}$ (Olsztyn). The current study showed fluorosis in $30.00 \%$ of the examined 15 -year-olds. Identical results (30\%) were obtained by Carvalho et al. [32]. In Germany, fluorosis was diagnosed in $7.1 \%-11.3 \%$ of patients [33], in Nigeria - 12.09\% [30], in Brazil - 17.2\% [34], in India - 24.5\% [35], in Yemen - 30.8\% [36], and in Mexico - 59\% [37]. By comparison, Ramesh M. et al. [38] reported very high dental fluorosis frequency (63.1\%) in a group of people living in the endemic fluorosed districs of Salem and Tamil Nadu. Naidu et al., when examining 15-year-old youths from Prakasam District in South India diagnosed dental fluorosis in 82.04\% of the populations [39].

The highest average number of teeth affected by fluorosis in the examined group from Sosnilka was recorded in sextant II - 3.52 and sextant V - 1.30. Bhavagatula et al. [3] proved that dental fluorosis was most frequently observed in upper incisors and least frequently in lower incisors. Studies by Sudhir [40] in Nalgonda, Andhra Pradesh District, south-east India, did not reveal any statistically significant differences between mandibular and maxillary incisor teeth. However, different results were obtained while examining 15-year-olds from Costa Rica. Salas-Pereira et al. [41] diagnosed the most severe form of dental fluorosis (moderate to severe) mostly in sextant III (25\%) and sextant II (12\%). According to de Moura et al. [42], the premolars were the teeth most affected by fluorosis. Wiener et al. [43] revealed that in a similar age group, $31.2 \%$ of those examined did not have dental fluorosis, $7.5 \%$ were diagnosed with questionable fluorosis and $61.3 \%$ with very mild and above. Own studies conducted in Sosnilka present respective values of $70.00 \%, 6.67 \%$ and $23.33 \%$. Different data concerning fluorosis severity in youths in Mexico is reported by de Lourdes Azpeitia-Valdez et al. [44]: very slight $-45.5 \%$, slight $-40.0 \%$, moderate $-11.8 \%$, and severe-2.6\%. Nelly Molina-Frechero et al. [37], while examining Mexican youths reported the following values: $29.3 \%$ - very mild fluorosis, $20.9 \%$ - mild fluorosis, $6.7 \%$ - moderate fluorosis, and $2.1 \%$ - severe fluorosis. Studies conducted by Celeste and others [45] on a large group of adolescents showed a prevalence of questionable cases (18.8\%), very mild, mild or moderate cases of dental fluorosis (11.5\%), and no severe cases observed. Froim a group of 1,026 students, $64.3 \%$ were detected with dental fluorosis, more than $50 \%$ had either severe or moderate fluorosis according to the Dean's fluorosis Index [46].

Research by Al-Akwa et al. [47] revealed a negative correlation between caries frequency and fluorine concentration in drinking water (0.61-2.00 ppm F-).

The conducted research revealed a highly significant negative correlation between the number of teeth affected by fluorosis and caries severity $(\mathrm{p}<0.001)$. A considerable influence of fluorine level in drinking water on the prevalence of dental fluorosis was detected by the research of Firempong et al. [48] in Ghana. In an examined group of youths from Bongo town, 63.0\% were diagnosed with dental fluorosis, whereas among those from villages outside the town - less than $10.0 \%$.

Analysis of own questionnaire showed that $61 \%$ of the examined youths brushed their teeth twice a day. Similar results were obtained by Carvalho et al. [32]. In both cases, no statistically significant correlation was observed with fluorosis incidence $(p=0.607)$. Lack of correlation between frequency of teeth-brushing and the type of toothpaste ( $p>0.15)$ was pointed out in the study by Celeste et al. [45].
Molina-Frechero et al. [37] revealed a correlation between fluorosis and more frequent teeth-brushing. Children who brushed more often had $28.5 \%$ more cases of fluorosis than those who brushed less frequently.

The available literature does not contain any studies concerning the correlation between prevalence of fluorosis and intake of fluorides from diet supplementation preparations and plant products. Similar conclusions were drawn by Bhagavatula et al. [3], whereas Khandare and Rao [9] claim that water and food are the main sources of fluoride for the humans. Fluorine content in plants depends mostly on its concentration in the soil, chemical composition of the soil, especially the of amount of calcium and phosphorus, as well as the type of soil $[10,49]$.

In own studies in Sosnilka, the average concentration of fluorine in the soil was $176 \mathrm{mg} \cdot \mathrm{dm}^{-3}$. Kulczycki et al.

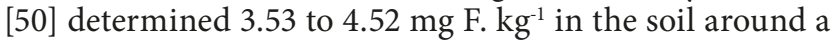
chemical plant near Bolesławiec in Silesia, south-west Poland. Kłódka et al. [51] stated that dissolved fluorine concentration in the soil influences its content in root vegetables. For leafy vegetables, the main sources of fluorine are its gaseous compounds. The authors determined $10-45 \mathrm{mg} \mathrm{F} \cdot \mathrm{kg}^{-1}$ in beetroot dry mass. In own studies, these values were much lower - $3.40 \mathrm{mg} \mathrm{F} \cdot \mathrm{kg}^{-1}$, on average. A higher concentration of fluorine in beetroot was reported by Kusa et al. [52] 15.91-29.04 $\mathrm{mg} \mathrm{F} \cdot \mathrm{kg}^{-1}$. It can be assumed that despite the quite high content of this element in water, its uptake by plants was impeded. Long-lasting, permanent fluoride contamination, even minimally exceeding the standards, is a toxic factor, thus its presence in the environment should be constantly monitored [53].

\section{CONCLUSION}

Close to optimal fluorine content lowers caries severity and frequency of fluorosis. Optimal fluorine content in drinking water and food does not require additional diet supplementation.

\section{REFERENCES}

1. Palczewska-Komsa M, Kalisińska E, Szmidt M, Stogiera A. Fluorosis in humans and animals. Med Środow. 2015; 18(4): 57-61.

2. Harding MA, Omullanne DM. Water fluoridation and oral health. Acta Med Acad. 2013; 42(2): 131-139. doi: 10.5644/ama2006-124.81

3. Bhagavatula P, Curtis A, Broffitt B, Weber-Gasparoni K, Warren JJ, Levy SM. The relationships between fluoride intake levels and fluorosis of late-erupting permanent teeth. J Public Health Dent. 2018; 78(2): 165-174. doi: 10.1111/jphd.12260

4. Narsimha A, Sudarshan V. Data on fluoride concentration levels in semi-arid region of Medak, Telangana, South India. Data Brief. 2017; 6(16): 717-723. doi: 10.1016/j.dib.2017.11.089

5. Skorowska-Zieleniewska J, Roszkowski W, Paprocka M. Fluorine in food - hygienic and nutritional problems and analytical. Metab. Fluoru. 1982; 15-19. (in Polish)

6. Boguszewska-Gutenbaum H, Turska-Szybka A, Remiszewski A. Dental Fluorosis - a Case Report. Nowa Stomatol. 2006; 11(2): 68-72.

7. Fawell J, Bailey K, Chilton J, Dahi E, Fewtrell L, Magara Y. London: IWA Publishers; Human health effects: Fluoride in drinking water WHO drinking-water quality series. 2006; p. 29-35.

8. Smolik B, Telesiński A, Szymczak J, Zakrzewska H. Assessing of humus usefulness in limiting of soluble fluoride content in soil. Ochr Środ Zasob Natur. 2011; 49: 202-208. (in Polish)

9. Khandare AL, Rao GS. Uptake of fluoride, aluminum and molybdenum by some vegetables from irrigation water. J Hum Ecol 2006; 19(4): 283-288. 
10. Baunthiyal M, Ranghar S. Accumulation of fluoride by plants: potential for phytoremediation. Clean Soil Air Water. 2013; 43(1): 127-132. doi. org/10.1002/clen.201300353

11. Telesiński A, Śnioszek M, Bioindicators of environmental pollution with fluorine. Bromat. Chem. Toksykol. 2009; (4): 1148-1154.

12. Jańczuk Z, Kaczmarek U, Lipski M. Conservative dentistry and endodontics. Clinical outline. Wyd. Lekarskie. PZWL, Warszawa. 2014; p. 201-210, 504-505. (in Polish)

13. Msyamboza KP, Phale E, Namalika JM, Mwase Y, Samonte GC et al. Magnitude of dental caries, missing and filled teeth in Malawi. National oral health survey. BMC Oral Health. 2016; (9): 16-29. doi: 10.1186/ s12903-016-0190-3

14. Han J, Bao-Jun T, Du MQ, Wei H, Bin P. Study of dental caries and the influence of social-behavioral risk factors on dental caries of 1,080 15-year-old adolescents. East Mediter. Health J. 2009; 15(4): 993-1004.

15. Pondingo-Loyola AP, Medina-Solis CE, Borges-Yaňez SA, Pati NoMartin N, Islas- Márguez A, Maupone G. Prevalence and severity of dental caries in adolescents aged 12 and 15 living in communities with various fluoride concentrations. J. Public. Health Dent. 2007; 67 (1): $8-13$.

16. El - Nadeef MA, Al Hussani E, Hassab H, Arab IA. National survey of the oral health of 12- and 15-year-old schoolchildren in the United Arab Emirates. East Mediter Health. 2009; 15 (4): 993-1004.

17. Hamissi J, Ramezani GH, Ghoduusia A. Prevalence of dental caries among high school attendees in Qazvin, Iran J Indian Soc Pedod Prev Dent. 2008; 26(2): 53-55.

18. Gorbatova MA, Gorbatova LN, Gribovski AM. Dental caries experience among 15-year-old adolescents in north-west Russia. Int J Circumpolar Health. 2007; 70(3): 232-235.

19. Milciuviene S, Bendoraitiene E, Andruskeviciene V, et al. Dental caries prevalence among 12-15-year-olds in Lithuania between 1983 and 2005 Medicine (Kaunas). 2009; 45(1): 68-76.

20. Doumit M, Doughan B. Dental caries and fluorosis among children in Lebanon. Indian J Dent Res. 2018; 29(3): 317-322.

21. Smolar N, Biezwuszko E, Czuhraj N, Dubiecka I, Szybinski W. Dental diseases of children inhabiting Lviv district. LNUM Lviv. 2012; p. 14-15.

22. Bachanek T, Chałas R, Zimenkovsky A, Hendzel B, Wolańska E, Samborski D, Pitura K et al. The content of chosen elements in drinking water and prevalence of caries and hygienic habits of 15 -year-old youth living in Lviv (Ukraine) and Lublin (Poland). J Elem. 2018; 23(2): 745-756. doi: 10.5601/jelem. 2017.22.4.1425

23. Oulis CJ, Tsinidou K, Vadiakas G, Mamai-Homata E, Polychronopouou A, Athanasouli T. Caries prevalence of 5, 12 and 15-year-old Greek children: A national pathfinder survey. Community Dent Health. 2012; 29(1): 28-32.

24. Sgan-Cohen HD, Margvelashvili V, Kalandadze M, Gordon M, Margvelashvili M, Zini A. Dental caries among children in Georgia by age, gender, residence location and ethnic group. Community Dent Health. 2014; 31(3): 163-166.

25. Goyal A, Gau K, Chwala HS, Kaur M, Kapur A. Epidemiology of dental caries in Chandigarh school children and trends over the last 25 years. J Indian Soc Pedod Prev Dent. 2007; 25(3): 115-118.

26. Ambrakova V, Jankulovska M, Arian D, Glavina D, Soleva A. Dental caries experience among secondary school children in the Vardar region of the Republic of Macedonia. Oral Health Dent Manag. 2014; 13(3): 805-810.

27. Results of epidemiological studies conducted in the programme "Monitoring of health of the oral cavity in 2011". Ministry of Health 2011. http://www.mz.gov.pl/wp content/uploads/2014/11/monitoring ju_2011.pdf

28. Hilt A, Rybarczyk-Townsend E, Wochna-Sobańska M. Dental status of junior high school students in Łódzkie voivodeship. Przegl Epidemiol. 2014; 68(1): 59-64

29. Meler J, Meler G. Fluidation of drinking water - advantages and disadvantages. J Elementol. 2006; 11 (3): 379-387.

30. Akosu TJ, Zoakah AL, Chirdan OA. The prevalence and severity of dental fluorosis in the high and low altitude parts of Central Plateau, Nigeria. Community Dent Health. 2009; 26(3): 138-142.

31. Jędra M, Sawilska-Rautenstrauch D, Gawarska H, Starski A. Fluorine content in total diets samples of small children in Poland. Rocz PZH. 2011; 3(62): 275-281

32. Carvalho TS, Kehrle HM, Sampaio FC. Prevalence and severity of dental fluorosis among students from João Pessoa, PB, Brazil. Braz Oral Res. 2007; 21(3): 198-203. doi: 10.1590/S1806-8324200700030000

33. Momeni A, Neuhäuser A, Ronner N, Heinzel-Gutenbrunner M, AbouFidah J, et al. Prevalence of dental fluorosis in german schoolchildren in areas with different preventive programmes. Caries Res. 2007; 41(6): 437-444.

34. Brandao IM, Peres AS, Saliba NA, Moimaz SA. Prevalence of dental fluorosis in school children from Marinópolis, São Paulo. Cad Saude Publica. 2002; 18(3): 877-881.

35. Rustagi N, Radhore AS, Meena JK, Chugh A, Pal R. Neglected health literacy undermining fluorosis control efforts: a pilot study among schoolchildren in an endemic village of rural Rajasthan, India. J Family Med Prim Care. 2017; 6(3): 533-537.

36. Kadir RA, Al-Maqutari RA. Endemic fluorosis among 14-year-old Yemeni adolescents: An exploratory survey. Int Dent J. 2010; 60(6): 407-410.

37. Molina-Frechero N, Gaona E, Angulo M, Sánchez-Pérez L, Gonzlez González R, Nevárez Rascón M, et al. Fluoride exposure effects and dental fluorosis in children in Mexico city. Med Sci Monit. 2015; (21): 3664-3670. doi: 10.12659/msm.895351

38. Rames M, Narasimhan M, Krishnan R, Aruna RM, Kuruvilla S. The effect of fluorosis on human teeth under light microscopy: a crosssectional study. J Oral Maxillofac Pathol. 2017; 21(3): 345-350.

39. Naidu GM, Rahamthullah SA, Kopuri RK, Kumar YA, Suman SV, Balagna RN. Prevalence and self-perception of dental fluorosis among 15 year old school children in Prakasham district of South India. J Int Oral Health. 2013; 5(6): 67-71.

40. Sudhir KM, Prashant GM, Subba Reddy VV, Mohandas U, Chandu GN. Prevalence and severity of dental fluorosis among 13- to 15-yearold school children of an area known for endemic fluorosis: Nalgonda district of Andhra Pradesh. J Indian Soc Pedod Prev Dent. 2009; 27(4): 190-196.

41. Salas-Pereira MT, Beltran-Aquilar ED, Chavarria P, Solórzano I, Horowitz H. Enamel fluorosis in 12- and 15-year-old school children in Costa Rica. Results of a national survey, 1999. Community Dent Health. 2008; 25(3): 178-184.

42. De Moura MS, Barbosa PR, Nunes dos Santos DL, Dantas-Neta NB, Moura de F, de Lima MDE. Epidemiological surveillance of dental fluorosis in a city with a tropical climate with a fluoridated public drinking water supply. Cien Saude Colet. 2016; 21(4): 1247-1254. doi: 10.1590/1413-81232015214.13852015

43. Wiener RC, Shen C, Findley P, Tan X, Sambamoorhi U. Dental fluorosis over time: a comparison of national health and nutrition examination survey data from 2001-2002 and 2011-2012. Hyg. 2018; 92(1): 23-29.

44. De Lourdes Azpeitia-Valadez M, Sánchez-Hernández MA, RgriquezFrausto M. Risk factors for dental fluorosis in children between 6 and 15 years old. Rev Med Inst Mex Sequero Soc. 2009; 47(3): 265-270.

45. Celeste RK, Luz PB. Independent and Additive Effects of Different Sources of Fluoride and Dental Fluorosis. Pediatr. Dent. 2016; 38(3): 233-238.

46. Verna A, Shett BK, Guddattu V, Chourasia MK, Pundir P. High prevalence of dental fluorosis among adolescents is a growing concern: a school based cross- sectional study from Southern India. Environ Health Prev Med. 2017; 22(1): 17. doi: 10.1186/s12199-017-0624-9

47. Al-Akwa AA, Al-Maweri. Dental caries prevalescence and its association with fluoride level in drinking water in Sanaa, Yemen. Eur. J. Dent. 2018; 12(1): 15-20.

48. Firempong C, Nsiah K, Awunyo-Vitor D, Dongsogo J. Soluble fluoride levels in drinking water-a major risk factor of dental fluorosis among children in Bongo community of Ghana. Ghana. Med J. 2013; 47(1): $16-23$.

49. Okibe FG, Ekanem EJ, Paul ED, Shallangwa GA, Ekwumemgbo PA, Sallau MS, Abanka OC. Fluoride content of soil and vegetables from irrigation farms on the bank of river Galma, Zaria, Nigeria. Australian J Basic Applied Sci. 2010; 4(5): 779-784.

50. Kulczycki G, Spiak Z, Kamińska A. Impact of Chemical Company „Wizów” on the content of fluorine in soil and plant. Zesz Nauk UP Wrocław. Rolnictwo. 2006; LXXXIX (546): 243-248.

51. Kłódka D, Musik D, Wójcik K, Telesiński A. Fluorine content in selected vegetables grown within the area affected by emission of that element from the "POLICE". Bromat Chem Toksykol. 2008; XLI (4): 964-969.

52. Kusa Z, Wardas W, Sochacka J, Pawłowska-Góral K. Fluoride Accumulation in Selected Vegetables During Their Vegetation. Pol J Environ Stud. 2004; 13(1): 55-58.

53. Stogiera A, Buczkowska-Radlińska J. Anthropogenic sources of fluorine - the impact on the environment and human health - a literature review. Dental Forum 2014; XLII: 57-62. doi: 10.20883/ issn.1732-0801.

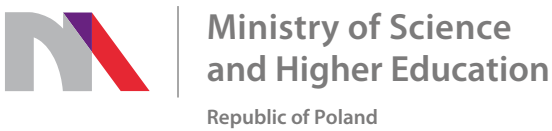

Generation of the DOI (Digital Object Identifier) - task financed under the agreement No. 618/P-DUN/2019 by the Minister of Science and Higher Education 